\title{
BRITISH EXPERIENCE WITH ARBITRATION *
}

\section{Charles L. Nordon $\dagger$}

No practical disquisition on this subject should neglect its psychological aspect. First of all, an observer is moved to enquire why the solution of justiciable disputes by Arbitration procedure is in many cases preferred to litigation in a country like England, whose judicial system and the probity, wisdom and incorruptibility of whose judiciary are alike the pride of its citizens and the admiration of its observers.

The growth of Arbitration is an obvious reflection upon the judicial courts of the country. If the latter provide all the citizen wants, the Arbitrator is not necessary. It should be noted at the outset, however, that an Arbitration does not connote quite the same degree of forensic hostility as a lawsuit and that the Englishman is imbued from youth upwards with the "spirit of the umpire" and obedience to the Referee's decision to an extent which perhaps is unknown in most other countries. Furthermore, he prefers a quick decision, even though adverse, to a favourable one coming too late to be of real service or to obviate the anxieties and delays of the waiting period. The writer will attempt in this paper to present the fruits of his experience in Arbitration and such of the advantages and many of the difficulties which that experience has brought to light.

To fill in the background of this experience and to answer this psychological query, it may be useful to differentiate the various types of cases in which resort is had to arbitration.

Strictly speaking, we should exclude those cases where the parties in framing a contract agree that price, quantity or quality, not defined with adequate certainty in the contract itself, is left to be fixed by Arbitration. From a precise juridical standpoint, that fixation is not Arbitration at all. It is merely an expression of the parties' intention to apply the rule id certum est, quod certum reddi potest, in order that their contract shall not be void for uncertainty. As soon as the quasi-Arbitrator, or valuer or expert, as he should more properly be called, has certified the price, quantity or quality, as the case may be, the parties are ad idem. In other words, the Arbitrator does not decide the rights of the parties to the contract, he merely forges the contractual nexus.

* It was planned to publish this article in the symposium on commercial arbitration presented in the December issue of this REview, but unavoidable circumstances have delayed its publication until the present number.

TLL. B., London University; solicitor of the Supreme Court of Judicature in England; member of the Standing Committee of Convocation of London University (Faculty of Laws); contributor to legal periodicals on a variety of subjects. 
There is next to be considered the submission to arbitration of any future disputes as to quality or value in a contract already definite in its terms. ${ }^{1}$ There the parties prefer to be bound by the decision of the expert applying his own accredited technical knowledge rather than by that of the nontechnical tribunal which hears and decides on the evidence of experts as witnesses. Of such Arbitrations the public hears but little. They seldom involve questions of law, and the Arbitrator decides upon the basis of his own inspection or technical test. In England such Arbitrations are by far the largest in number. Most trade associations have their "panels" of Arbitrators, who for a fee of a few guineas are ready to express their opinion on the physical subject matter of the dispute, often without hearing or at most after reading statements of the adversaries' conflicting contentions.

Then there are the submission clauses in contracts to provide for future Arbitrations before any dispute has arisen, the parties by their contract seeking to avoid court litigation. Submissions of this kind may be sub-divided into:-

(a) Where the parties agree, in a contract drafted ad hoc and of their own free choice, that possible disputes thereunder shall be arbitrated, and

(b) Where the person who wishes to do business with a particular company or firm is obliged, whether he likes it or not, to accept the latter's printed form of contract containing an Arbitration clause protecting its author from the jurisdiction of the courts.

Finally, there is the agreement, simpliciter, to submit to Arbitration, without any precedent obligation, a dispute which has already arisen, but which the parties are under no legal compulsion to arbitrate.

British practice in dealing with these situations has been largely governed by statute. The modern Arbitration tribunal is the creation of the Arbitration Act, I889, ${ }^{2}$ which has served a useful public need during its 45 years of currency and has only this year been amended by the Act of $1934 .^{3}$

It is interesting to observe that Arbitration is now upon an international basis. Effect was given by the Arbitration Clauses (Protocol) Act, I924, ${ }^{4}$ to the Ieague of Nations Protocol ${ }^{5}$ providing for the international recognition of the validity of submissions to arbitration made between the parties who are subject to the jurisdiction of different contracting states. For this reason it is very important that in submissions to Arbitration by parties of

I. Scott v. Avery, 5 H. L. C. 8II (1856); cf. In re Fletcher, 237 N. Y. 440,143 N. E. 248 (1924), (1924) 34 YALE L. J. 98.

2. 52 \& 53 VICT., C. 49 (I88g).

3. 24 \& 25 Geo. V, C. 14 (1934).

4. I4 \& I5 GEo. V, c. 39 (I924).

5. Protocol on Arbitration Clauses, League of Nations Official Journal (Supp. I923) 342 . 
different nationality, the country where the Arbitration is to be held and whose law is to govern the dispute should be specified. Otherwise the Arbitration would be held in the country where performance is due, and its lex loci would be applied.

In spite of certain difficulties in procedure which arise from time to time, Arbitration in England seems in practice to work reasonably well. Notwithstanding the enormous number of Arbitrations in the course of the year, there are relatively few which proceed for review in the Courts, though perhaps this may be attributable to the consequential expense. Rapidity is of course the chief allurement of the Arbitration Chamber and this aspect is now reinforced by Section 6 of the 1934 Act $^{6}$ which gives the Court power to remove a dilatory Arbitrator. ${ }^{7}$

After 45 years experience with the Act of 1889 , Parliament has not thought fit to make any very drastic alterations in it by the 1934 Act $^{8}$ of which the principal provisions deal with:-

(I) Death or bankruptcy of parties to submission.

(2) Increased powers of court in the matter of appointments of Arbitrator and Umpire.

(3) Power to remove a dilatory Arbitrator.

(4) Power to order specific performance of a contract; security for costs; discovery of documents; affidavit evidence; examination of witnesses on commission in a foreign country; the detention, preservation or inspection of the property the subject of the reference; interim injunctions and the appointment of a receiver.

(5) Limitation on the right of appeal from the decision of the court on cases stated by the Arbitrator.

(6) Power to enter judgment in terms of the award.

(7) Power to assess or tax the Arbitrator's remuneration. trator.

(8) Further relief against partiality or misconduct of the Arbi-

(9) Application of the Statute of Limitations to claims in Arbitration where award is made a condition precedent to the accrual of a cause of action; and power to review time clause in a contract barring claims unless arbitration is commenced within a specified period.

The particulars in which the Act of $\mathrm{i} 889$ has proved unsatisfactory give some idea of the details in which English arbitration procedure has been found wanting. The Act of 1934 points clearly to matters in which strict regulation has been found necessary. But one factor most important in any arbitration is not-and cannot-be covered by these statutes. That is the question of the person and the personality of the Arbitrator.

6. $24 \& 25$ GEo. V, c. 14 (1934).

7. See Vitaphone Corp. v. Electrical Research Products, Inc., Ig Del. Ch. 247, I66 Atl. 255, I9 Del. Ch. 354, I67 Atl. 845 (1933), sub nom. Electrical Research Products, Inc. r. Vitaphone Corp., I7I Atl. 738 (Del. Sup. Ct. I934), (1933) 47 HARv. L. REv. I26; (1933) 33 COL. L. REv. 1440; Phillips, Rules of Law or Laissez-Faire in Commercial Arbitration (I933) 47 HARv. L. REv. 590.

8. Supra note 6. 
We first find "Arbitrator" defined in Giles Jacob's Law Dictionary (published in 1729 and dedicated to Sir Robert Raymond, then Lord Chief Justice of England) :-

"An Arbitrator is a private extraordinary. Judge between Party and Party, chosen by their mutual Consents, to determine Controversies between them. And Arbitrators are so called because they have an arbitrary Power; for if they observe the Submission and keep within due bounds their Sentences are definitive, from which there lies no Appeal. (I Roll. Abr. 25I.)" 9

The modern development of arbitration has, however, falsified that definition, for the decision of an Arbitrator is now open to review in nearly every case where the decision of a Judge would be subject to appeal. The machinery for review, however, as I shall endeavour to shew, is in many respects cumbrous and unsatisfactory, and a party who has insufficient knowledge of modern practice and procedure may easily be subjected to injustice.

By the law as it stands today an Arbitrator, curiously enough, need possess no judicial qualifications and he owes no legal responsibility (except in case of fraud) to those who seek his services. The importance of his function belies the minimum of capability which is required.

Historically, the Arbitrator's freedom from responsibility is not justified. His precursor under Roman law, the Judex or private judge, appointed by the prætor or magistrate under the terms of a submission or formula, was liable ex maleficio if he gave a wrong decision. The reason for this liability, even although it arose from ignorance, was that the Judex could always avail himself of the services of the juris prudentes (the equivalent of the legal assessor of to-day) or could have recourse for guidance to the prætor who had assigned the action to him for trial. Similar assistance is obtainable by the present-day Arbitrator, but if he does not avail himself of it and goes astray he is immune from the consequences of his error. Every member of the legal profession and many of the commercial community know to their sorrow how costly such consequences may be, especially to the party in whose favour an erroneous award is given in the first instance. If arbitrations are to continue in favour it is of pressing importance that the first decision shall be the correct one so far as human wisdom can secure, and that the arbitrator shall be liable for any egregious error which he commits.

A successful conclusion to an Arbitration can be incurred only by wide knowledge on the part of the Arbitrator. No Arbitrator can safely proceed with an Arbitration unless familiar with the provisions of the 1889 Act (and, in foreign arbitrations, of the I924 and I930 Acts). Moreover, as from Ist January, I93.5, he will be required to know the extent to which the

9. Jacob, New Law Dictronary (I729) tit. "Arbitrator". 
I889 Act is varied by the I934 Act, unless and until, as is probable, Parliament in due course passes a codifying Act amalgamating and reconciling the provisions of both. He must also be familiar with case law affecting not only Arbitration procedure but also the subject matter of the dispute, as well as with the relevant statutes.

Nevertheless the foregoing essentials do not in practice preclude the "lay" Arbitrator from acting in cases where legal knowledge and experience is essential. The difficulty is overcome by the introduction of the "Legal Assessor" who either sits with the Arbitrator or advises him afterwards on the legal questions which arise and who usually drafts the award. Thus the lay Arbitrator is saved from mistakes or oversights in matters of strict law whilst still remaining the Arbiter on questions of fact or opinion. The validity of this conventional procedure has never yet been tested. It might be argued that an Award in such circumstances is not the Award of the Arbitrator chosen by the parties; or that the Arbitrator must not listen (particularly in privacy) to any views upon the subject of the dispute other than those of the parties. But there is no doubt of the practical value of the device.

It will no doubt be conceded that the procedure of appointing two Arbitrators and an Umpire is cumbersome and archaic. The Arbitrators appointed by each party are in practice advocates for their nominators, and if, as they almost invariably conceive to be their duty, they fail to agree, the parties are put to the expense of a re-hearing before the Umpire. On the other hand, if a submission before 1934 provided for three Arbitrators their award had to be unanimous to be binding. In a paper on Arbitration which the writer read before the Law Society in $1926^{10}$ he suggested that if in a special case three Arbitrators are considered necessary, then the award of the majority should be decisive, subject to review for any mistake appearing on the face of it. Effect was given to this suggestion by Section 4 of the I934 Act which also gives legislative sanction to certain other suggestions contained in the same paper.

The writer foresees that with the gradual evolution of Arbitration no person will by law be permitted to act as Arbitrator who has not proved himself by examination to have some knowledge of legal principles and particularly of the rules of evidence. It seems a curious anomaly that although, in order to protect the public against ignorant legal practitioners, no person may practise as an advocate in the courts until he has given evidence of sufficient training in the law, yet any unqualified person may be allowed to adjudicate in an Arbitration with serious, costly and far-reaching consequences. I do not propose to lay down in detail the professional requirements I should prescribe, but suggest that no person other than a competent lawyer or an accountant whose professional examination has included legal subjects should

10. Nordon, Arbitratron (1926) (Solicitors' Law Stationery Society, London). 
be permitted to act as Arbitrator (otherwise than in trade or technical disputes of quality or value) unless he shall first have passed a qualifying examination, to be conducted by a joint committee of the councils of the professions I have indicated. Moreover, if such qualification is insisted upon there should be no need for the parties to incur the additional expense, to which they almost invariably have to submit in a case before a lay Arbitrator where legal questions are raised, of having the Arbitrator guided by a legal assessor who in practice writes the award.

Of late years trade associations have evolved the practice of maintaining individual panels of Arbitrators. On first thought it would seem that a member of the trade having special knowledge of its practice and customs is a suitable Arbitrator for disputes arising therein. But to this it can be answered that such an Arbitrator may not have sufficient knowledge of the rules of evidence or of the legal principles applicable to the dispute. Furthermore his very membership in the trade and his personal acquaintance with one or the other of the parties may place him in an embarrassing position and perhaps affect his independent judgment. This last objection, of course, would not apply to the cases where the parties agree on a specified individual as Arbitrator (which is always the preferable course), but only to those where the president of the association makes the appointment.

Difficulties of the kind I have briefly suggested, and others of like character, could be overcome by the appointment as Registrar of Arbitrations, of the Senior Master of the Supreme Court in London and the District Registrars in the provinces. These Registrars would compile and maintain a panel of properly qualified Arbitrators comprising the leading commercial practitioners willing and fitted to act in that capacity. For cases involving technical questions such a tribunal should be composed of those possessing special knowledge in each particular industry. Then on the application of either party the Registrar from his panel would submit six names to both parties and request them to agree upon one mutually acceptable who would thereupon be the chosen Arbitrator. On any unreasonable refusal to agree the Registrar would make his own selection.

While no substantial steps in this direction have as yet been taken, it should be noted that the London Chamber of Commerce has established an arbitration procedure of its own, which it has committed to the charge of a body styled the "London Court of Arbitration" (the use of the word "court" being in this respect somewhat misleading). The Chamber recommends that parties to commercial contracts insert the following clause:-

The construction and performance of this Contract shall be governed by the Law of England and all disputes which may arise under, out of or in connection with or in relation to this Contract shall he submitted to the arbitration of the London Court of Arbitration under its Rules at the date hereof. 
This clause is open to objection, for it gives no certain guide to the parties or to the Arbitrator as to how far the statutory provisions. are incorporated. Moreover, the allusion to the reference of disputes to the "London Court of Arbitration" may be deceiving; some people will be misled into the belief that their controversy is to be settled by the full court, and not, as is actually the case, by the particular individual whom that body chooses to nominate. My plea in this respect is for complete and statutory unification of procedure so that "Arbitration" shall mean the same thing in every document, namely Arbitration under the statutory provisions for the time being in force, subject to any special agreement which the parties may make with their eyes open and in plain terms. For example, in Scrimaglio v. Thornett, ${ }^{11}$ the contract provided: "Any dispute arising out of this Contract to be settled by Arbitration in London in the usual way." It was decided that this does not mean the dispute was to be settled (as one of the parties thought) by an ordinary Arbitration under the Arbitration Act; on the contrary, the clause was held to contemplate the usual, but not invariable way by which disputes in that trade are settled in London.

On the question of rapidity it is clear nothing is gained if the Arbitrator follows the same procedure as in an action, namely, ordering successively points of claim, defence, reply, discovery and interrogatories. It would be preferable that an intending plaintiff in an arbitration should, without waiting for the appointment of an Arbitrator, serve by registered post upon the proposed defendant a "demand for Arbitration" setting forth in full particulars the nature of his complaint and the amount of his claim. This "demand" should be accompanied by a list of the documents relied on, of which another copy would be be given to the Arbitrator when appointed. The defendant should be obliged within seven days to serve the plaintiff with his "Arbitration answer" accompanied by similar lists of any additional documents on which he desires to rely. If the defendant raises a counterclaim the plaintifif should deliver his "Arbitration reply" within three days, similarly accompanied by lists of any further documents. The issues being thus defined, the dispute would be promptly ready for adjudication and its nature as thus disclosed would help the parties to agree upon or the court or trade organisation to specify a suitable Arbitrator. In order to safeguard the parties against willful suppression or falsification of documentary evidence penalties should be provided for punishment of such malpractice.

Next, a few words as to the form in which the award should be drawn. I consider that an Arbitrator should in every case, whether specially requested or not, publish his award in a reasoned form. ${ }^{12}$ If that practice were made uniform Arbitrators would have to listen to the evidence and study the

I1. I3I L. T. R. (N. S.) I74 (Ct. App. I924).

12. Cf. Fraenkel, Procedural Aspects of Arbitration (1934) 83 U. of PA. L. REv. 226. 
legal arguments with greater care than they sometimes do at present. It would also be desirable that, in addition to giving reasons for his award and dealing with any points of law raised by either party, the Arbitrator should append a reference to the documents given to him for the purposes of the Arbitration together with a note of the evidence given by the witnesses, so that the court of review (should review be inevitable) would then have before it all the necessary material. In cases where a sworn shorthand writer does not record the evidence I suggest that it should be part of the duty of the Arbitrator to take a sufficient note and to read it over to the witness in the presence of the parties before dismissing him.

Unlike the judicial judgment, the Arbitrator's award cannot per se be carried into execution against an unwilling party; the order of the court is essential in dealing with a recalcitrant loser. Usually, however, this order, though involving expense and delay, is a mere formality; the court, by its own mandate and without rehearing, authorises issuance of execution, attachment or like remedy to enforce the Arbitrator's award.

The inexperienced party to an Arbitration is apt to congratulate himself on having escaped the expense and delay of the law courts. But very often he finds himself in a "fool's paradise". For instance, Section 7 of the Arbitration Act, I889,13 gave the Arbitrator power, but did not compel him, to state his award in the form of a special case for the opinion of the court. Having done that, if he would do it, he was functus officio and thenceforward only the court could deal with his award. The Section 7 case would be set down before a single judge-usually the Commercial Judge-from whose decision an appeal would lie without leave. Under Section I9 of the Act the Arbitrator might and could be compelled to state, in the form of a special case for the opinion of the court, any question of law arising in the course of the reference. This having been done, the Arbitration would be suspended until the Divisional Court (or a Chancery Judge if the case be referable to the latter) had given the Arbitrator its opinion. But that opinion when expressed was not an order, did not bind the rights of the parties and bestowed no right of appeal. If, however, the Arbitrator incorporated in his award the opinion of the court given on the special case under this section, the comical result followed that an application to set aside the award for an error appearing on the face of it must be refused by the court of first instance who would be bound to say that the incorporated law stated by their colleagues in their opinion was right. It was then, however, open to the complaining party to appeal from this second decision and to ask the Court of Appeal to set aside or remit the award. ${ }^{14}$ Under Section Io of the Arbitra-

13. Supra note 2.

14. British Westinghouse Electric \& Manufacturing Co., Ltd. v. Underground Electric Railways Co., [19I2] A. C. 673. 
tion Act the Court still has power to remit any award with a direction to the Arbitrator to re-state it in the form of a special case in order to raise a specified point of law.

The foregoing difficulties are remedied to some extent by Section 9 of the I934 Act which authorises and empowers the court to compel an Arbitrator to state any question of law or any part of his award in the form of a special case for the decision of the court. Moreover Section 19 of the I889 Act is now repealed by Section 2 I of the I934 Act. But even these provisions do not wholly eliminate the disadvantages. There have been many recent cases where the judicial bench has commented on the extravagant waste of time and money in cases where, by reason of the complex nature of the legal questions, Arbitration has proved only a preliminary step in the elucidation and determination of the issues. That complexity usually arises from the lack of business care and foresight of the parties in entering into the transaction out of which the Arbitration arises. In such cases, unless privacy is essential and can be guaranteed by the mutual acceptance of the Arbitrator's award as conclusive, experience shows that arbitration is not the most effective means of settlement.

The substitution of Arbitration for the judicial bench should be based upon good and sufficient reason. What then is the preferring motive? Economy it can seldom be, for solution by Arbitration in a "full dress" dispute is just as expensive as a law suit. Solicitors' and counsels' fees are no less. The Arbitrator has to be paid by the parties or at least by the loser, whereas the Judge is paid by the State. Expedition cannot always be the motive, for, if either party so wishes, the procedure in Arbitration is just as dilatory as in the courts. Whereas the court, once it starts the hearing, continues de die in diem, the Arbitrator studying the engagements of himself, the advocates, the parties and their witnesses, is often compelled to arrange a series of short appointments spread over a considerable period of time. The picking up of the broken threads at each resumed hearing adds to the length of time involved. Further extravagance in time arises where there are two Arbitrators and an Umpire, or where either party requires an advisory case to be stated under Section I9 of the Arbitration Act I889 or the award in the form of a special case under Section 7 .

Accordingly, if neither economy nor rapidity is to be obtained in the "full dress" Arbitration, ${ }^{15}$ what is the object which the parties to Arbitration have at heart? The answer is privacy. They don't want their affairs discussed in public. Here is the constitutional pendulum swinging the other way. Our Constitution makers used to insist that our judges could not be trusted to do their duty unless they sat under public scrutiny; consequently litigants were exposed to the gossip monger. To escape the latter's atten-

15. From this category may be excluded quality disputes decided by a trade or scientific expert upon view or examination. Supra p. 315. 
tions the parties are driven to the privacy of the Arbitration room-presided over by the Arbitrator, whose qualifications and even whose impartiality can never be certified.

In what cases then does British experience shew that Arbitration is mutually advantageous? They seem to be limited to those where (I) privacy or (2) rapidity are essential or (3) where the dispute involves simply a pure question of fact or technical opinion, such, for example, as whether goods are merchantable or up to sample, or whether a given piece of machinery will function. I cannot conceive any other cases where a private Arbitrator will prove, in the long run, a more suitable tribunal than the appropriate court of the country. It should be pointed out, however, that privacy cannot be secured unless the parties agree that they will not ask the Arbitrator to "state a case" or otherwise apply to the court for review, but will treat the award as final. Furthermore, if the desire for privacy is, as I have suggested, the primary reason for the growth of Arbitration, why should it be withheld from the private citizen? No party likes his name perpetuated in the law reports as having been involved in a legal dispute which lays down a judicial principle, any more than a hospital patient likes to undergo a surgical operation before a class of students. In the matter of rapidity, under present procedure, if either party or the Arbitrator is dilatory the commercial court may prove to be the more speedy tribunal. On the question of expense, unless the Arbitrator is thoroughly familiar with his duties and is willing to accept a reasonable fee, an Arbitration may ultimately be less economical than a lawsuit.

The foregoing observations, based on and resulting from a long practical experience, seem perhaps to suggest that if Arbitration procedure fulfils a function which is absent from judicial procedure, then a strong case arises for that omission to be made good constitutionally rather than be supplied by amateur or non-official judges.

Consequently, it will be seen that Arbitration is unnecessary in some instances, and that the present system is inadequate in others. For those cases which are the legitimate object of Arbitration the commercial man requires a uniform but simple code of Arbitration procedure so that in suitable cases Arbitration may take and retain its rightful place as the substitute for, but not the competitor with the Judicial Bench.

\section{ApPENDIX}

\section{Notes on Decided Cases in the English Courts}

Czarnikow v. Roth, [I922] 2 K. B. 478: A sugar contract was expressed to be subject to the Rules of the Refined Sugar Association which required that members making contracts should refer any disputes to arbitration under the Rules. Rule I9 provided that the parties would not apply to the Court to require arbitrators to state in the form of a special case for 
the opinion of the court any question of law arising in the reference, but that such question of law should be determined in the arbitration.

In a dispute between buyers and sellers on such a contract the buyers requested the arbitrators to settle a case under Section 7 or alternatively under Section I9 of the Act on certain questions of liability arising in the reference. The arbitrators refused to comply and made their award which the buyers moved to set aside on the ground of misconduct of the arbitrators.

The court held that Rule I9 was contrary to public policy and invalid as it involved the ouster of the statutory jurisdiction of the courts under the Arbitration Act and that the award must be set aside.

Palmer v. Pilot, 45 T. L. R. 2I4 (K. B. D. I929): In contract for sale of wax it was provided that any dispute should be settled by arbitrators in London in the usual way. The appointed arbitrators selected an umpire by a document headed "The use of this form constitutes a submittion to the Rules of the London Oil and Tallow Trades Association". The umpire decided that the defendants' claim failed and that they were to pay the cost of the arbitration.

The Rules of the Association provided for an appeal to an appeal committee and the defendants claimed a right thereunder. The plaintiffs brought an action against the defendants for the costs of the arbitration. Evidence was adduced that in the paraffin wax trade the usual way of settling a dispute by arbitration was to appoint arbitrators who could appoint an umpire whose decision would be final.

It was held that the heading on the document was irrelevant and that the umpire was really appointed in pursuance of the original agreement and not under the Rules of the Association and that there was no appeal.

Ronaasen v. Metsanomistajain, Div. Ct. $40 \mathrm{Ll}$. L. Rep. 267. (I9I3) : In a contract for the sale of timber it was provided that any dispute should be referred to arbitration which it might be found impossible to settle within Io days of a notification to the seller's agents specifying the items complained of and the monetary amount claimed. The timber was rejected by the buyers as not being in accordance with the contract and they refused to appoint an arbitrator. The sellers proceeded with arbitration and an award was made. The buyers then applied to set aside award on the ground that the dispute was not within the submission.

Held, that the dispute as to buyer's right to reject was not covered by the arbitration clause and the award was set aside.

H. Ford \& Co. v. Compagnie Furness, [I922] 2 K. B. 797 : Charterparty provided that disputes should be referred to arbitration, claimant's arbitrator to be appointed within the time limited, and if he was not so appointed the claim was to be deemed waived and barred.

A loss to cargo was suffered owing to the ship's unseaworthiness. Cargo owners claimed damages and went to arbitration, but did not appoint an arbitrator within the time limited. An award was made in their favour, the shipowners not appearing.

It was held that although the loss was caused by unseaworthiness and the cargo owners were entitled to go to arbitration, they could only do so in accordance with the terms of the contract which had not been complied with and so the arbitrator had no jurisdiction to make the award. 
Absalom v. Great Western (London) Garden Village Society, [ro33] A. C. 592 : A building contract provided that as and when work to the value of $\mathfrak{E}_{\mathrm{I}, 000}$ had been executed, architect's certificates should be given entitling the contractors to payment at the rate of $90 \%$ of the value of the work until the I0\% retained should amount to $\mathfrak{E}_{2}, 000$, and that any dispute which might arise should be referred to an arbitrator. It was also provided that if the contractors should suspend work except in case of a certificate being withheld, the architect might give notice to the contractors to proceed with all diligent despatch.

During the progress of the work the contractors claimed a further substantial sum which had not been included in the architect's certificates, but the employers claimed that the contractors had been overpaid and that no certificate was due to them. Thereupon the contractors stopped work. The parties submitted to an arbitrator the disputes in regard to the issue of certificates and the validity of the notice to the contractors to proceed. The arbitrator decided that a sum of $\mathfrak{E}_{793}$ remained due to the contractors but that the architect had nevertheless issued certificates in accordance with the terms of the contract and that the contractors were in default.

It was held that the arbitrator had erred in his construction of the contract in holding that after the value of the work had reached $\sum_{1,000}$ it was still necessary that $E x, 000$ should be due to the contractors in order to entitle them to a certificate; that the construction of the contract had not been expressly or specifically left to the arbitrator; and that his award should be set aside for error in law appearing on the face of it.

Barton v. Blackburn, I50 L. T. R. 327 (Ct. App. I933): The articles of partnership on amalgamation of two firms provided that the shares of profits should be reviewed and if necessary revised in I923 and again in I926 in such manner as might be agreed, or in case of disagreement, settled by a special arbitrator. Such articles were to be deemed a submission to arbitration under the Act. The partners could never agree whether there should be a review and on dissolution provision was made for statements and counter-statements to be exchanged, with the further stipulation that if the parties then failed to agree, the dispute was to be referred to the special arbitrator under the Articles. The dispute was then referred to the special arbitrator and the parties agreed that certain questions of Law should be decided with the assistance of a Chancery King's Counsel, sitting as assessor, at a preliminary hearing. It was further agreed that either party should have the same right of appeal against any decision of the arbitrator as if there had been no preliminary hearing. The special arbitrator was ordered by the court to state a special case which he incorporated in his award. The Court of Appeal by a majority held that this was a case where questions of law became material to the dispute, and that the court could interfere if an error in law appeared on the face of the award. 